\title{
pH- and Time-Dependent Release of Phytohormones from Diruthenium Complexes
}

\author{
Isabel Coloma, Miguel Cortijo, Inés Fernández-Sánchez, Josefina Perles, José L. Priego, \\ Crisanto Gutiérrez, Reyes Jiménez-Aparicio, Bénédicte Desvoyes,* and Santiago Herrero*
}

Cite This: Inorg. Chem. 2020, 59, 7779-7788

Read Online

ACCESS | Lill Metrics \& More | 回 Article Recommendations | Sl Supporting Information

ABSTRACT: The controlled release of functionally active compounds is important in a variety of applications. Here, we have synthesized, characterized, and studied the magnetic properties of three novel metal-metal-bonded tris(formamidinato) $\mathrm{Ru}_{2}^{5+}$ complexes. We have used different auxin-related hormones, indole-3-acetate (IAA), 2,4-dichlorophenoxyacetate (2,4-D), and 1-naphthaleneacetate (NAA), to generate $\left[\mathrm{Ru}_{2} \mathrm{Cl}(\mu \text {-DPhF })_{3}(\mu\right.$-IAA) $]$ (RuIAA), $\left[\mathrm{Ru}_{2} \mathrm{Cl}(\mu \text {-DPhF })_{3}(\mu-2,4-\mathrm{D})\right](\mathbf{R u 2 , 4 - D})$, and $\left[\mathrm{Ru}_{2} \mathrm{Cl}(\mu \text {-DPhF })_{3}\left(\mu\right.\right.$-NAA)] (RuNAA) (DPhF $=N, N^{\prime}$-diphenylformamidinate). The crystal structures of RuIAA, RuIAA $\cdot \mathrm{THF}, \mathrm{Ru} 2,4-\mathrm{D} \cdot \mathrm{CH}_{2} \mathrm{Cl}_{2}$, and RuNAA $\cdot 0.5$ THF have been determined by single-crystal Xray diffraction. To assess the releasing capacity of the bound hormone, we have employed a biological assay that relied on Arabidopsis thaliana plants expressing an auxin reporter gene and we demonstrate that the release of the phytohormones from RuIAA, Ru2,4-D, and RuNAA is pH- and time-dependent. These studies serve as a proof of concept showing the potential of these types of compounds as biological molecule carriers.

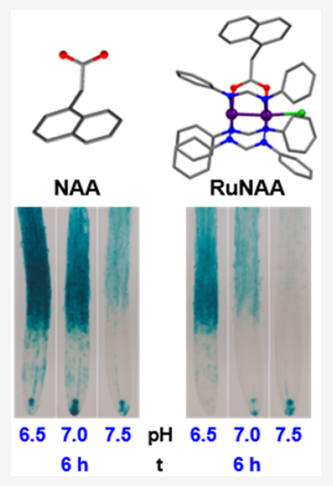

\section{INTRODUCTION}

Drug delivery systems can help overcome one of the most important limitations in cancer chemotherapy: the lack of efficacy in discriminating between cancer and healthy cells. Many different approaches have been studied, including the use of metal-containing materials such as metallic nanoparticles ${ }^{1}$ or metallopolymers ${ }^{2}$ as carriers. The anticancer activity of discrete metal complexes ${ }^{3}$ and, particularly, organic pharmaceutical containing diruthenium(II,III) complexes with a paddlewheel structure has also been explored. ${ }^{4}$

Dinuclear complexes with a paddlewheel structure, in which two metal-metal-bonded atoms are bridged by four ligands, are well-known types of complexes that have been intensively studied in the last few decades. ${ }^{5,6}$ Diruthenium compounds with this type of structure have been a subject of interest mainly because they display singular electronic and magnetic properties. In particular, the family of tetracarboxylatodiruthenium complexes is one that has been studied in more detail. ${ }^{7,8}$ Most of these compounds are formally mixed-valence $\mathrm{Ru}(\mathrm{II})-\mathrm{Ru}$ (III) complexes, although it is better to consider them as averaged valence compounds containing $\mathrm{Ru}_{2}^{5+}$ units. Moreover, $\mathrm{Ru}_{2}^{4+}$ compounds can also be isolated using carboxylate ligands. 9

SCF-X $\alpha$-SW calculations carried out on $\left[\mathrm{Ru}_{2}\left(\mu-\mathrm{O}_{2} \mathrm{CR}\right)_{4}\right]^{+}$ complexes showed that the $\mathrm{Ru}_{2}^{5+}$ unit shows a quasidegeneration of the $\pi^{*}$ and $\delta^{*}$ energy levels, leading to a $\mathrm{Q} \pi^{* 2} \delta^{*}$ electronic configuration (where $\mathrm{Q}$ denotes the underlying $\sigma^{2} \pi^{4} \delta^{2}$ core) with three unpaired electrons and a metal-metal bond order of 2.5. ${ }^{10}$ The use of amidinate ligands, which have a higher donor character in comparison to carboxylates, allows isolation of not only $\mathrm{Ru}_{2}^{4+}$ and $\mathrm{Ru}_{2}^{5+}$ compounds but also $\mathrm{Ru}_{2}^{6+}$ compounds. ${ }^{11,12}$ Again, the $\mathrm{Ru}_{2}^{5+}$ oxidation state is the most common one in this family of compounds. Furthermore, heteroleptic compounds with different ratios of carboxylate/amidinate bridging ligands can be prepared by varying the synthetic conditions employed. ${ }^{13}$ Depending on the nature of the ligands, it is possible to obtain $\mathrm{Ru}_{2}^{5+}$ compounds with high $\left(\mathrm{Q} \pi^{* 2} \delta^{*}\right)$, low $\left(\mathrm{Q} \delta^{* 2} \pi^{*}\right.$ or $\left.\mathrm{Q} \pi^{* 3}\right)$, or intermediate-spin configurations. ${ }^{11}$

Another interesting aspect of these types of compounds is their potential interaction with biological systems. It is important to note that they offer different stereochemistry in comparison to mononuclear complexes that increases their possibilities of interaction. It has been recently shown that the $\left[\mathrm{Ru}_{2} \mathrm{Cl}_{2}(\mu \text {-DPhF })_{3}(\mathrm{DMSO})\right]$ complex, which displays an openpaddlewheel structure (three bridging ligands instead of four), can be a useful reagent to obtain information about the secondary structure of RNAs. This compound interacts covalently with nucleotides placed at, or in the neighborhood of, double-strand/single-strand junctions of a stem-loop structured RNA, providing information complementary to that obtained with other reagents that specifically react with singlestranded RNA loops. ${ }^{14}$ In order to get more insight into the interactions of $\left[\mathrm{Ru}_{2} \mathrm{Cl}_{2}(\mu-\mathrm{DPhF})_{3}\right]$ with nucleic acids, the

Received: March 23, 2020

Published: May 15, 2020 
coordination capacity of cytosine, adenine, and derivatives to diruthenium species was also studied. Those species are coordinated as a bridge to two equatorial positions of diruthenium fragments, leaving the axial positions available to form additional interactions with other residues. This could explain the preference of the diruthenium moieties to RNA junctions. ${ }^{15}$ It was previously reported that diruthenium compounds can interact with biological substances through the axial ${ }^{16}$ or equatorial positions ${ }^{17-20}$ and that they can form metal-protein adducts. ${ }^{19}$ Interestingly, some diruthenium compounds have shown anticancer activity against rat and human glioma cells ${ }^{21,22}$ and breast and prostate cancer cells. ${ }^{20}$

It is well-known, on one hand, that solid tumors present extracellular acidosis ( $\mathrm{pH}$ 6.5-7.1 or even lower values) due to high rates of lactic acid production and low rates of diffusion while normal tissues have a $\mathrm{pH}$ of $\sim 7.4 .^{23-26}$ On the other hand, the paddlewheel $\left[\mathrm{Ru}_{2} \mathrm{Cl}(\mu-\mathrm{DPhF})_{3}\left(\mu-\mathrm{O}_{2} \mathrm{CMe}\right)\right]$ complex releases the carboxylate ligand in the presence of dilute hydrochloric acid in methanol to form the open-paddlewheel complex $\left[\mathrm{Ru}_{2} \mathrm{Cl}_{2}(\mu-\mathrm{DPhF})_{3}\right]$ (Scheme 1$) .{ }^{27}$ Therefore, we

Scheme 1. Schematic Representation of MeCOOH Release in the Reaction of $\left[\mathrm{Ru}_{2} \mathrm{Cl}(\mu-\mathrm{DPhF})_{3}\left(\mu-\mathrm{O}_{2} \mathrm{CMe}\right)\right]$ with Dilute $\mathrm{HCl}$

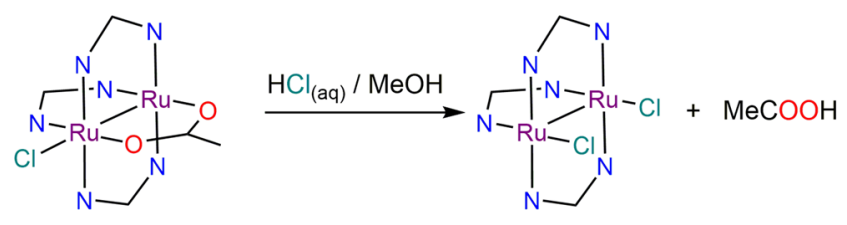

hypothesized that diruthenium complexes could be used, for example, as carriers of anticancer drugs, or other biologically active compounds, containing a carboxylate group to be released in the acidic environment of solid tumors. As a first step to that goal, we aimed at investigating the coordination/release properties of biologically active species by using diruthenium moieties.

In order to study the kinetic release of the ligands, we have employed auxins. These phytohormones are involved in different processes during plant growth and development, regulating cell proliferation and differentiation in various tissues. $^{28}$ Auxins are important regulators of the root architecture, and plant exogenous treatment leads to the inhibition of the primary root growth and promotes the formation of lateral roots. More importantly, their biological activity in plants can be monitored after a short exposure time and detected specifically even at very low concentrations. In addition, auxins are easy to assess and do not present any ethical concerns. Thus, we have prepared tris(formamidinato)diruthenium complexes with a paddlewheel structure carrying $O, O^{\prime}$-donor auxin ligands (Figure 1 ) in order to study their potential $\mathrm{pH}$-controlled release in a complex environment.

\section{EXPERIMENTAL SECTION}

General Materials and Methods. $\left[\mathrm{Ru}_{2} \mathrm{Cl}_{2}(\mu \text {-DPhF })_{3}\right]$ was prepared according to a published procedure. ${ }^{27}$ The rest of the reactants and solvents were obtained from commercial sources and used as received. Elemental analyses were done by the Microanalytical Service of the Complutense University of Madrid. FT-IR spectra were recorded with a PerkinElmer Spectrum 100 instrument that has a universal ATR accessory. Electrospray ionization (ESI) mass spectra were collected by the Mass Spectrometry Service of the Complutense University of Madrid using an ion trap-Bruker Esquire-LC

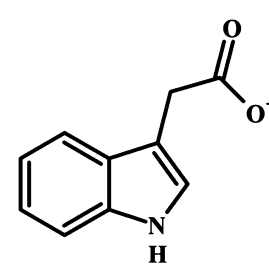

IAA<smiles>O=C([O-])COc1ccc(Cl)cc1Cl</smiles>

2,4-D<smiles>O=C(O)Cc1cccc2ccccc12</smiles>

NAA
Figure 1. Auxins employed in this study: indole-3-acetate (IAA), 2,4dichlorophenoxyacetate (2,4-D), and 1-naphthaleneacetate (NAA).

spectrometer. Electronic spectra of dichloromethane solutions of the complexes with an $\sim 10^{-4} \mathrm{M}$ concentration were recorded using a Cary $5 \mathrm{G}$ spectrometer. Variable-temperature magnetization measurements were performed on a Quantum Design MPMSXL SQUID magnetometer. All data were corrected for the diamagnetic contribution to the susceptibility of both the sample holder and the compound.

Single-Crystal X-ray Diffraction Data Collection and Structure Refinement. Single crystals of RuIAA, RuIAA-THF, and Ru2,4D. $\mathrm{CH}_{2} \mathbf{C l}_{2}$ were measured at 100,250 , and $150 \mathrm{~K}$, respectively, with a Bruker Kappa Apex II system, while RuNAA•0.5THF was measured at $296 \mathrm{~K}$ using a Bruker Smart-CCD diffractometer, both with graphitemonochromated Mo K $\alpha$ radiation $(\lambda=0.71073 \AA$ ) from conventional sealed tubes. CCDC 1988474-1988477 contain the crystallographic data for RuIAA, RuIAA-THF, Ru2,4-D $\cdot \mathrm{CH}_{2} \mathbf{C l}_{2}$, and RuNAA $0.5 T H F$, respectively. These data can be obtained free of charge from the Cambridge Crystallographic Data Centre via www.ccdc.cam.ac.uk/ data_request/cif. A summary of selected crystal structure data can be found in Table 1.

More crystallographic information can be found in Figures S1-S10 and Tables $\mathrm{S} 1-\mathrm{S} 8$ in the Supporting Information.

Syntheses. Synthesis of $\left[R u_{2} C l(\mu-D P h F)_{3}(\mu-I A A)\right]$ (RuIAA). A solution of $0.05 \mathrm{~g}$ of NaIAA $(0.25 \mathrm{mmol})$ in $2 \mathrm{~mL}$ of water was added to a suspension of $0.20 \mathrm{~g}$ of $\left[\mathrm{Ru}_{2} \mathrm{Cl}_{2}(\mu-\mathrm{DPhF})_{3}\right](0.23 \mathrm{mmol})$ in $4 \mathrm{~mL}$ of acetone. The dark bluish purple suspension obtained was stirred for 3 days. The mixture was filtered, and the solid was washed with $3 \times 3 \mathrm{~mL}$ of a $1 / 1$ water/acetone mixture, $2 \times 3 \mathrm{~mL}$ of methanol, and $2 \times 3 \mathrm{~mL}$ of a $2 / 1$ diethyl ether/petroleum ether mixture and dried under vacuum. Yield: $0.19 \mathrm{~g}(81 \%)$. Anal. Found (calcd) for $\mathrm{C}_{49} \mathrm{H}_{41} \mathrm{ClN}_{7} \mathrm{O}_{2} \mathrm{Ru}_{2} \cdot 2 \mathrm{H}_{2} \mathrm{O}\left(1033.542 \mathrm{~g} \mathrm{~mol}^{-1}\right): \mathrm{C}, 56.78$ (56.94); $\mathrm{H}$, 4.28 (4.39); $\mathrm{N}, 9.42$ (9.49). IR: $\tilde{\nu}\left(\mathrm{cm}^{-1}\right) 3621 \mathrm{w}, 3430 \mathrm{w}, 3260 \mathrm{w}$, $3056 \mathrm{w}, 2965 \mathrm{w}, 1618 \mathrm{w}, 1593 \mathrm{~m}, 1530 \mathrm{vs}, 1485 \mathrm{vs}, 1458 \mathrm{~m}, 1408 \mathrm{~s}, 1317 \mathrm{~s}$, $1214 \mathrm{vs}, 1125 \mathrm{~m}, 1098 \mathrm{~m}, 1076 \mathrm{~m}, 1026 \mathrm{~m}, 1010 \mathrm{w}, 956 \mathrm{~m}, 939 \mathrm{~m}, 841 \mathrm{w}$, 804w, 774m, 756s, 742s, 724s, 690vs, 655s. UV/vis/NIR $\left(\mathrm{CH}_{2} \mathrm{Cl}_{2}\right)$ : $\lambda_{\max } / \mathrm{nm}\left(\varepsilon / \mathrm{M}^{-1} \mathrm{~cm}^{-1}\right) 517(4700), \sim 570 \mathrm{sh}(4300), \sim 640 \mathrm{sh}(2800)$. MS (ESI $\left.{ }^{+}\right): m / z$ 963.1, [M $\left.-\mathrm{Cl}\right]^{+}$. Crystals of RuIAA and RuIAA $\cdot$ THF suitable for single crystal X-ray diffraction were obtained by slow diffusion of hexane into a THF solution of the compound. Although both presented a dark purple color, their habit and size were different.

Synthesis of $\left[R u_{2} C l(\mu-D P h F)_{3}(\mu-2,4-D)\right](R u 2,4-D)$. A 0.05 g portion of $\mathrm{H} 2,4-\mathrm{D}(0.23 \mathrm{mmol})$ was dissolved in $4 \mathrm{~mL}$ of an acetone/water $1 / 1$ mixture. This solution was added to a mixture of $0.20 \mathrm{~g}$ of $\left[\mathrm{Ru}_{2} \mathrm{Cl}_{2}(\mu-\right.$ $\left.\mathrm{DPhF})_{3}\right](0.23 \mathrm{mmol})$ in $4 \mathrm{~mL}$ of acetone. The dark bluish purple mixture obtained was stirred for 3 days, at which point the solid was filtered, washed with $2 \times 2 \mathrm{~mL}$ of a $1 / 1$ water/acetone mixture, $1 \mathrm{~mL}$ of methanol, and $1 \mathrm{~mL}$ of diethyl ether, and dried under vacuum. Yield: $0.19 \mathrm{~g}(79 \%)$. Anal. Found (calcd) for $\mathrm{C}_{47} \mathrm{H}_{38} \mathrm{Cl}_{3} \mathrm{~N}_{6} \mathrm{O}_{3} \mathrm{Ru}_{2}(1043.364 \mathrm{~g}$ $\left.\mathrm{mol}^{-1}\right)$ : C, 54.22 (54.11); H, 3.84 (3.67); N, 8.01 (8.05). IR: $\tilde{\nu}\left(\mathrm{cm}^{-1}\right)$ $3060 \mathrm{w}, 2968 \mathrm{w}, 1592 \mathrm{~m}, 1547 \mathrm{~s}, 1527 \mathrm{vs}, 1486 \mathrm{vs}, 1450 \mathrm{~s}, 1426 \mathrm{~s}, 1317 \mathrm{~s}$, $1290 \mathrm{~s}, 1270 \mathrm{~m}, 1219 \mathrm{vs}, 1153 \mathrm{~m}, 1119 \mathrm{~m}, 1105 \mathrm{~m}, 1073 \mathrm{~s}, 1027 \mathrm{~m}, 1002 \mathrm{~m}$, $954 \mathrm{~m}, 939 \mathrm{~m}, 906 \mathrm{~m}, 858 \mathrm{~m}, 838 \mathrm{~m}, 805 \mathrm{~s}, 773 \mathrm{~s}, 759 \mathrm{~s}, 729 \mathrm{~m}, 716 \mathrm{~m}$, 693vs, 658s. UV/vis/NIR $\left(\mathrm{CH}_{2} \mathrm{Cl}_{2}\right): \lambda_{\max } / \mathrm{nm}\left(\varepsilon / \mathrm{M}^{-1} \mathrm{~cm}^{-1}\right) 527$ (4500), $\sim 564 \operatorname{sh}(4300), \sim 641 \mathrm{sh}(3000)$. MS $\left(\mathrm{ESI}^{+}\right): m / z$ 1008.0, $[\mathrm{M}$ $-\mathrm{Cl}]^{+} ; 864.0,\left[\mathrm{Ru}_{2}(\mathrm{DPhF})_{3}\left(\mathrm{O}_{2} \mathrm{CCH} \mathrm{H}_{2} \mathrm{OH}\right)\right]^{+}$; 848.0, $\left[\mathrm{Ru}_{2}(\mathrm{DPhF})_{3}\left(\mathrm{O}_{2} \mathrm{CCH}_{3}\right)\right]^{+}$; 833.0, $\left[\mathrm{Ru}_{2}(\mathrm{DPhF})_{3}\left(\mathrm{O}_{2} \mathrm{CH}\right)\right]^{+}$. Crystals of $\mathbf{R u} 2,4-\mathrm{D} \cdot \mathbf{C H}_{2} \mathbf{C l}_{2}$ suitable for single-crystal X-ray diffraction were 
Table 1. Crystal and Refinement Data of RuIAA, RuIAA THF, Ru2,4-D $\cdot \mathrm{CH}_{2} \mathrm{Cl}_{2}$, and RuNAA $\cdot 0.5 \mathrm{THF}$

\begin{tabular}{|c|c|c|c|c|}
\hline & RuIAA & RuIAA $\cdot$ THF & $\mathrm{Ru} 2,4-\mathrm{D} \cdot \mathrm{CH}_{2} \mathrm{Cl}_{2}$ & RuNAA $0.5 T H F$ \\
\hline$T / \mathrm{K}$ & 100 & 250 & 150 & 296 \\
\hline formula & $\mathrm{C}_{49} \mathrm{H}_{41} \mathrm{ClN}_{7} \mathrm{O}_{2} \mathrm{Ru}_{2}$ & $\mathrm{C}_{49} \mathrm{H}_{41} \mathrm{ClN}_{7} \mathrm{O}_{2} \mathrm{Ru}_{2} \cdot \mathrm{C}_{4} \mathrm{H}_{8} \mathrm{O}$ & $\mathrm{C}_{47} \mathrm{H}_{38} \mathrm{Cl}_{3} \mathrm{~N}_{6} \mathrm{O}_{3} \mathrm{Ru}_{2} \cdot \mathrm{CH}_{2} \mathrm{Cl}_{2}$ & $\mathrm{C}_{51} \mathrm{H}_{42} \mathrm{ClN}_{6} \mathrm{O}_{2} \mathrm{Ru}_{2} \cdot 0.5 \mathrm{C}_{4} \mathrm{H}_{8} \mathrm{O}$ \\
\hline $\mathrm{fw}$ & 997.48 & 1069.61 & 1128.28 & 1044.58 \\
\hline space group & $P \overline{1}$ & $\mathrm{C} 2 / c$ & $\mathrm{C} 2 / \mathrm{c}$ & $P \overline{1}$ \\
\hline$a / \AA$ & $10.0070(5)$ & $31.8361(9)$ & $33.622(1)$ & $12.7237(5)$ \\
\hline$b / \AA$ & $14.2862(9)$ & $10.7930(2)$ & $15.9552(6)$ & $13.3262(5)$ \\
\hline$c / \AA ̊$ & $15.477(1)$ & $27.6895(8)$ & $20.0006(7)$ & $16.1951(6)$ \\
\hline$\alpha / \operatorname{deg}$ & $83.813(2)$ & 90 & 90 & $68.462(1)$ \\
\hline$\beta /$ deg & $81.775(2)$ & $97.307(1)$ & $120.957(2)$ & $86.833(1)$ \\
\hline$\gamma / \mathrm{deg}$ & $77.596(2)$ & 90 & 90 & $84.925(1)$ \\
\hline$V / \AA^{3}$ & $2131.9(2)$ & $9437.0(4)$ & $9200.9(6)$ & $2543.5(2)$ \\
\hline Z & 2 & 8 & 8 & 2 \\
\hline$d_{\text {calcd }} / \mathrm{g} \mathrm{cm}^{-3}$ & 1.554 & 1.506 & 1.629 & 1.364 \\
\hline$\mu / \mathrm{mm}^{-1}$ & 0.821 & 0.749 & 0.997 & 0.692 \\
\hline$R$ indices $(I>2 \sigma(I))$ & $R_{1}=0.0379, w R_{2}=0.0625$ & $R_{1}=0.0303, w R_{2}=0.0589$ & $R_{1}=0.0320, w R_{2}=0.1063$ & $R_{1}=0.0421, w R_{2}=0.1290$ \\
\hline GOF on $F^{2}$ & 1.028 & 1.265 & 1.004 & 1.043 \\
\hline
\end{tabular}

obtained by slow diffusion of hexane into a dichloromethane solution of Ru2,4-D.

Synthesis of $\left[R u_{2} C l(\mu-D P h F)_{3}(\mu-N A A)\right]$ (RuNAA). A 0.05 g portion of KNAA $(0.23 \mathrm{mmol})$ was dissolved in $2 \mathrm{~mL}$ of water and added to a mixture of $0.20 \mathrm{~g}$ of $\left[\mathrm{Ru}_{2} \mathrm{Cl}_{2}(\mu-\mathrm{DPhF})_{3}\right](0.23 \mathrm{mmol})$ in $4 \mathrm{~mL}$ of acetone. The dark bluish purple mixture was stirred for 3 days. The solid obtained was filtered, washed with $3 \times 2 \mathrm{~mL}$ of a $1 / 1$ water/acetone mixture and $2 \mathrm{~mL}$ of diethyl ether, and dried under vacuum. Yield: 0.21 $\mathrm{g}(90 \%)$. Anal. Found (calcd) for $\mathrm{C}_{51} \mathrm{H}_{42} \mathrm{ClN}_{6} \mathrm{O}_{2} \mathrm{Ru}_{2} \cdot \mathrm{H}_{2} \mathrm{O}(1026.55 \mathrm{~g}$ $\mathrm{mol}^{-1}$ ): C, 59.78 (59.67); H, 4.14 (4.32); N, 8.23 (8.19). IR: $\tilde{\nu}\left(\mathrm{cm}^{-1}\right)$ $3056 \mathrm{w}, 2954 \mathrm{w}, 1593 \mathrm{~m}, 1531 \mathrm{vs}, 1486 \mathrm{vs}, 1450 \mathrm{~m}, 1408 \mathrm{~s}, 1393 \mathrm{~m}, 1318 \mathrm{~s}$, $1220 \mathrm{~s}, 1158 \mathrm{~m}, 1064 \mathrm{~m}, 1027 \mathrm{~m}, 958 \mathrm{~m}, 939 \mathrm{~m}, 908 \mathrm{~m}, 840 \mathrm{w}, 793 \mathrm{~m}$, $786 \mathrm{~m}, 773 \mathrm{~s}, 755 \mathrm{vs}, 715 \mathrm{~m}, 694 \mathrm{vs}, 659 \mathrm{~s}$. UV/vis/NIR $\left(\mathrm{CH}_{2} \mathrm{Cl}_{2}\right): \lambda_{\max } /$ $\mathrm{nm}\left(\varepsilon / \mathrm{M}^{-1} \mathrm{~cm}^{-1}\right) 525$ (4600), $572 \mathrm{sh}(4300), \sim 642 \mathrm{sh}(3100)$. MS $\left(\mathrm{ESI}^{+}\right): m / z$ 974.1, $[\mathrm{M}-\mathrm{Cl}]^{+}$. Crystals of RuNAA $\cdot 0.5$ THF suitable for single-crystal X-ray diffraction were obtained by slow diffusion of hexane into a THF solution of RuNAA.

Biological Assays to Measure Auxin Activity. Transgenic Arabidopsis thaliana seeds carrying pDR5::GUS ${ }^{29}$ were surfacesterilized with a $20 \%$ commercial bleach and rinsed with sterile water. After 2 days of stratification at $4{ }^{\circ} \mathrm{C}$, seeds were sown on plates containing $1 / 2$ Murashige and Skoog medium supplemented with 0.5 g/L MES (2-( $N$-morpholino)ethanesulfonic acid) $\mathrm{pH} 5.7,1 \%$ sucrose, and $1 \%$ Plant Agar (Duchefa). Plates were maintained vertically to allow root growth during 5 days at $21^{\circ} \mathrm{C}$ under long day conditions (16 $\mathrm{h}$ light $/ 8 \mathrm{~h}$ dark) and $60 \%$ moisture. For the experiments, a fresh solution of each auxin, sodium indole-3-acetate (NaIAA), dichlorophenoxyacetic acid (H2,4-D), and potassium 1-naphthaleneacetate (KNAA), and each diruthenium compound, RuIAA, Ru2,4-D, and RuNAA, was prepared at $10 \mathrm{mM}$ in DMSO. Plants were then transferred to six-well plates containing $1 \mu \mathrm{M}$ of NaIAA, RuIAA, KNAA, or RuNAA or $5 \mu \mathrm{M}$ of H2,4-D or Ru2,4-D in a 5 mM HEPES$\mathrm{KOH}$ (4-(2-hydroxyethyl)-1-piperazineethanesulfonic acid) buffer at $\mathrm{pH} 6.5,7$, and 7.5. Plants were incubated during $1.5-24 \mathrm{~h}$ at room temperature. At each time point, a histochemical assay was performed, incubating the plants for $2 \mathrm{~h}$ at $37^{\circ} \mathrm{C}$ in the GUS assay buffer $(100 \mathrm{mM}$ $\mathrm{NaH}_{2} \mathrm{PO}_{4} / \mathrm{Na}_{2} \mathrm{HPO}_{4}$ buffer at $\mathrm{pH} 7,0.5 \mathrm{mg} / \mathrm{mL}$ of X-Gluc (5-bromo4-chloro-3-indolyl- $\beta$-D-glucuronide), $2 \mathrm{mM} \mathrm{K} \mathrm{K}_{3}\left[\mathrm{Fe}(\mathrm{CN})_{6}\right], 2 \mathrm{mM}$ $\left.\mathrm{K}_{4}\left[\mathrm{Fe}(\mathrm{CN})_{6}\right]\right)$. Roots were imaged with an Axioskop2 microscope (Zeiss) coupled to a DMC6200 color camera (Leica), and image processing was performed using FIJI. ${ }^{30}$

\section{RESULTS AND DISCUSSION}

Synthesis and Characterization of the Compounds. The incorporation of carboxylate ligands into diruthenium complexes has usually been carried out by the substitution of acetate groups in $\left[\mathrm{Ru}_{2} \mathrm{Cl}\left(\mu-\mathrm{O}_{2} \mathrm{CMe}\right)_{4}\right]^{7,8}$ at high temperatures.
The same principle has been used to replace acetate ligands by other carboxylates in $\left[\mathrm{Ru}_{2} \mathrm{Cl}(\mu-\mathrm{DPhF})_{3}\left(\mu-\mathrm{O}_{2} \mathrm{CMe}\right)\right]$ in refluxing solvents ${ }^{31,32}$ or solvothermal conditions under microwave radiation. ${ }^{33}$ However, those methods are limited to very stable ligands. Therefore, in order to work at room temperature to introduce sensitive ligands, another synthetic strategy has to be employed. One alternative is the use of the very reactive openpaddlewheel compound $\left[\mathrm{Ru}_{2} \mathrm{Cl}_{2}(\mu \text {-DPhF })_{3}\right] .15$ Thus, RuIAA, Ru2,4-D, and RuNAA were obtained by the addition of a water/ acetone or a water solution of the corresponding auxin or auxin salt (see the Experimental Section) into a dark blue suspension of $\left[\mathrm{Ru}_{2} \mathrm{Cl}_{2}(\mu \text {-DPhF })_{3}\right]$ in acetone at room temperature. The suspension changed immediately from blue to bluish purple in all cases. The three compounds can be isolated with a ca. $60 \%$ yield after stirring the reaction mixture for $15 \mathrm{~min}$, filtering, and washing the solid profusely with methanol to eliminate the remaining starting material. Nevertheless, if the reaction time is increased to 3 days, it is possible to isolate them with yields ranging from 79 to $90 \%$. The gain in stability of the diruthenium species from an open-paddlewheel to a paddlewheel structure probably acts as the driving force of the reaction. ${ }^{34}$ In fact, the reaction is probably almost instantaneous. However, the reaction rate could be limited by the low solubility of $\left[\mathrm{Ru}_{2} \mathrm{Cl}_{2}(\mu-\mathrm{DPhF})_{3}\right]$ in the reaction mixture that was selected to reduce its potential decomposition in solution prior to the reaction.

The IR spectra of RuIAA, Ru2,4-D, and RuNAA display symmetric $\left(1426-1408 \mathrm{~cm}^{-1}\right)$ and antisymmetric $(1547-1530$ $\mathrm{cm}^{-1}$ ) $\mathrm{O}-\mathrm{C}-\mathrm{O}$ stretching absorption bands due to the carboxylate groups of the auxin ligands. The separation of these two bands is similar in all of the spectra $\left(\sim 130 \mathrm{~cm}^{-1}\right)$, which suggests the same coordination mode for the carboxylate ligands in all of the complexes. This separation is compatible with a bridging coordination mode. ${ }^{35}$ The IR spectra and the assignment of the most relevant bands are shown in Figure S11 in the Supporting Information and in Table 2, respectively.

The electronic spectra of RuIAA, Ru2,4-D, and RuNAA and the precursor $\left[\mathrm{Ru}_{2} \mathrm{Cl}(\mu-\mathrm{DPhF})_{3}\left(\mu-\mathrm{O}_{2} \mathrm{CMe}\right)\right]$ present the same profile (Figure S12 and Table 3), typical of high-spin $(S=3 / 2)$ carboxylatotris(formamidinato)diruthenium complexes. ${ }^{27}$ All of the spectra show an absorption in the range $515-527 \mathrm{~nm}$ that can be ascribed to a $\pi\left(\mathrm{RuO} / \mathrm{N}, \mathrm{Ru}_{2}\right) \rightarrow \pi^{*}\left(\mathrm{Ru}_{2}\right)$ transition and two shoulders between 565 and $572 \mathrm{~nm}$ and between 640 and 
Table 2. Tentative Assignment of Some Relevant Bands $\left(\mathrm{cm}^{-1}\right)$ of the IR Spectra of RuIAA, Ru2,4-D, and RuNAA

\begin{tabular}{llll} 
& \multicolumn{1}{c}{ RuIAA } & Ru2,4-D & RuNAA \\
$\nu(\mathrm{N}-\mathrm{H})$ & 3260 & & \\
$\nu\left(\mathrm{C}_{\text {arom }}-\mathrm{H}\right)$ & 3056 & 3060 & 3056 \\
$\nu\left(\mathrm{C}_{\text {aliph }}-\mathrm{H}\right)$ & 2965 & 2968 & 2954 \\
$\nu\left(\mathrm{C}=\mathrm{C}_{\text {arom }}\right)$ & 1595,1485 & 1592,1486 & 1593,1486 \\
$\nu_{\text {as }}(\mathrm{O}-\mathrm{C}-\mathrm{O})$ & 1530 & 1547 & 1531 \\
$\nu_{\mathrm{s}}(\mathrm{O}-\mathrm{C}-\mathrm{O})$ & 1408 & 1426 & 1408 \\
$\nu(\mathrm{C}-\mathrm{N})$ & 1317,1214 & 1317,1219 & 1318,1220 \\
\hline
\end{tabular}

$665 \mathrm{~nm}$ that are assigned to $\pi^{*}\left(\mathrm{Ru}_{2}\right) \rightarrow \sigma^{*}(\mathrm{RuN})$ and $\delta\left(\mathrm{Ru}_{2}\right) \rightarrow$ $\pi^{*}\left(\mathrm{Ru}_{2}\right)$, respectively ${ }^{31,36}$ (Table 3 ).

The ESI ${ }^{+}$mass spectra of the complexes are shown in Figure 2. Although none of the mass spectra show the molecular peak, the base peak of all of them corresponds to the $[\mathrm{M}-\mathrm{Cl}]^{+}$fragments at $m / z$ 963, 1008, and 974 for RuIAA, Ru2,4-D, and RuNAA, respectively. The isotope pattern of these peaks agrees well with the calculated distribution as can be observed in Figure 2 . Additional peaks with very low intensity are observed in the spectrum of Ru2,4-D and ascribed to the fragmentation of the 2,4-D ligand.

Single crystals of compounds RuIAA, RuIAA $\cdot$ THF, and RuNAA $\cdot 0.5$ THF were obtained by slow diffusion of hexane in a solution of the corresponding complex in THF, while crystals of $\mathrm{Ru} 2,4-\mathrm{D} \cdot \mathrm{CH}_{2} \mathrm{Cl}_{2}$ were obtained by diffusion of hexane in a solution of Ru2,4-D in dichloromethane, and their structures were solved by single-crystal X-ray diffraction. Selected bond lengths and angles are presented in Table 4, and more structural and refinement data can be found in the Experimental Section (Table 1) and Figures $\mathrm{S} 1-\mathrm{S} 10$ and Tables $\mathrm{S} 1-\mathrm{S} 8$ in the Supporting Information.

All of the complexes display paddlewheel diruthenium units (see Figure 3), where the two ruthenium atoms show metalmetal bonds and are bridged by three $N, N^{\prime}$-diphenylformamidinates and one carboxylate ligand, and a chloride ligand is axially coordinated. All of the bond distances and angles present the expected values for this kind of compounds. $\mathrm{Ru}-\mathrm{Ru}$ distances are in the range 2.3147(3)-2.3213(4) $\AA$, typical for a diruthenium paddlewheel compound with a 2.5 bond order and a $\sigma^{2} \pi^{4} \delta^{2} \pi^{* 2} \delta^{*}$ electronic configuration. ${ }^{11}$

With regard to the supramolecular interactions, the strongest ones were found in RuIAA and RuIAA THF: the nitrogen atom in the IAA ligand participates in $\mathrm{N}-\mathrm{H} \cdots \mathrm{Cl}$ bonds with the axial chloride ligand from a neighboring molecule to yield pairs of paddlewheel dimers in both structures (Figure S6). These synthons are bonded with adjacent pairs through weaker $\mathrm{C}-\mathrm{H} \cdots$ $\mathrm{O}$ interactions involving the carboxylic $\mathrm{O} 2$ atom to form chains in the [101] direction in RuIAA (Figure S7, left), while in the case of RuIAA - THF these interactions are established with two oxygen atoms from interstitial THF moieties, generating groups of four molecules instead (Figure S7, right).
In $\mathbf{R u} 2,4-\mathrm{D} \cdot \mathrm{CH}_{2} \mathrm{Cl}_{2}$ only weak $\mathrm{C}-\mathrm{H} \cdots \mathrm{O}$ and $\mathrm{C}-\mathrm{H} \cdots \mathrm{Cl}$ interactions (involving both chlorine atoms from the phytohormone as well as the axial $\mathrm{Cl}^{-}$ligand) are present between the paddlewheel molecules, to yield an intermolecular 3D arrangement. Finally, in the structure of RuNAA 0.5 THF, supramolecular chains are found in the [100] direction achieved through $\mathrm{C}-\mathrm{H} \cdots \mathrm{Cl}$ bonds, where the NAA ligand is not involved.

It is worth noting that a Cambridge Structural Database ${ }^{38}$ search at the time of this writing yielded only one compound with the natural auxin IAA: $\left[\mathrm{Cu}_{2}(\mu \text {-IAA })_{4}(\mathrm{DMF})_{2}\right]$ (GEXRAC entry $\left.{ }^{39}\right)$. However, many crystal structures with synthetic auxins have been described: 62 structures of complexes containing 2,4$\mathrm{D}$ and 75 structures of complexes containing NAA. Among them, only a few display a paddlewheel structure: $\left[\mathrm{Cu}_{2}(\mu-2,4-\right.$ D $\left.)_{4} \mathrm{~L}_{2}\right] \quad\left(\mathrm{L}=2\right.$,4-dioxane, ${ }^{40} \mathrm{H}_{2} \mathrm{O},{ }^{41}$ pyridine-3-carboxylic $\left.\operatorname{acid}^{42}\right), \quad\left[\mathrm{Cu}_{2}(\mu-2,4-\mathrm{D})_{4}(\mathrm{pyz})\right]_{n}{ }^{43}\left[\mathrm{Cd}_{2}(\mu-2,4-\mathrm{D})_{4}(\mathrm{bpy})_{2}\right]{ }^{44}$ $\left[\mathrm{Ni}_{2}(\mu-2,4-\mathrm{D})_{4}(\mathrm{DMF})_{2}\right],{ }^{45}\left[\mathrm{Cu}_{2}(\mu-\mathrm{NAA})_{4} \mathrm{~L}_{2}\right]\left(\mathrm{L}=\mathrm{DMF}{ }^{46}\right.$ $\left.\mathrm{DMSO}^{47}\right), \quad\left[\mathrm{Cu}_{4}(\mu-\mathrm{NAA})_{8}\left(\mathrm{NCCH}_{3}\right)_{2}\right],{ }^{48}\left[\mathrm{Zn}_{2}(\mu-\mathrm{NAA})_{4}(6-\right.$ phenyl-1,3,5-triazine-2,4-diamine $\left.)_{2}\right],{ }^{49}$ and $\left[\mathrm{Ru}_{2}(\mu\right.$ $\left.\mathrm{NAA})_{4}\left(\mathrm{OH}_{2}\right)_{2}\right]\left(\mathrm{PF}_{6}\right){ }^{50}$

Powder X-ray diffraction (PXRD) measurements were carried out in bulk samples of the complexes crystallized as explained above. Although two different types of single crystals of RuIAA were simultaneously obtained by crystallization in a THF/ hexane mixture, the PXRD measurement of the bulk sample shows that RuIAA-THF is the main product, but the few additional peaks detected in the diffractogram could account for the presence of a small amount of the nonsolvated compound (Figure S8). The data obtained for Ru2,4-D and RuNAA show that a single phase is obtained in both cases (Figures S9 and S10).

Magnetic Properties. Magnetization measurements at 0.5 T were carried out for samples of RuIAA, Ru2,4-D, and RuNAA in the $2-300 \mathrm{~K}$ range of temperatures. Figure 4 shows the temperature dependence of both the molar magnetic susceptibility $\left(\chi_{M}\right)$ and the product of the molar magnetic susceptibility by the temperature $\left(\chi_{\mathrm{M}} T\right)$ of RuIAA and also the fit of the data with the model described below (eqs 1-3). The plots of the data and the fits obtained for Ru2,4-D and RuNAA are shown in Figures S13 and S14 in the Supporting Information.

The $\chi_{M} T$ values at room temperature of RuIAA, Ru2,4-D, and RuNAA are $1.98,1.93$, and $1.94 \mathrm{~cm}^{3} \mathrm{~K} \mathrm{~mol}^{-1}$, respectively, which are slightly higher than the expected spin-only value for an $S=3 / 2$ system with $g=2\left(1.87 \mathrm{~cm}^{3} \mathrm{~K} \mathrm{~mol}^{-1}\right)$. On cooling, the $\chi_{\mathrm{M}} T$ value decreases in all cases, which is typically observed in these types of complexes. ${ }^{11}$ This behavior originates mainly from a zero-field splitting (ZFS), and for this reason the experimental $\chi_{M}$ and $\chi_{M} T$ data were fitted using eqs $1-3$, which describe a quadruplet state undergoing an axial ZFS.

$$
\chi_{M}=\frac{\chi_{\|}+2 \chi_{\perp}}{3}
$$

Table 3. Tentative Assignment of the Transitions (nm) of the Electronic Spectra of $\left[\mathrm{Ru}_{2} \mathrm{Cl}(\mu \text {-DPhF })_{3}\left(\mu-\mathrm{O}_{2} \mathrm{CMe}\right)\right]$, $^{27} \mathrm{RuIAA}$, Ru2,4-D, and RuNAA

\begin{tabular}{lccc}
\multicolumn{1}{c}{ compound } & $\pi\left(\mathrm{RuO} / \mathrm{N}, \mathrm{Ru}_{2}\right) \rightarrow \pi *\left(\mathrm{Ru}_{2}\right)$ & $\pi *\left(\mathrm{Ru}_{2}\right) \rightarrow \sigma^{*}(\mathrm{RuN})$ & $\delta\left(\mathrm{Ru}_{2}\right) \rightarrow \pi^{*}\left(\mathrm{Ru}_{2}\right)$ \\
{$\left[\mathrm{Ru}_{2} \mathrm{Cl}(\mu \text { - } \mathrm{DPhF})_{3}\left(\mu-\mathrm{O}_{2} \mathrm{CMe}\right)\right]$} & 515 & $565 \mathrm{sh}$ & $665 \mathrm{sh}$ \\
RuIAA & 517 & $570 \mathrm{sh}$ & $640 \mathrm{sh}$ \\
Ru2,4-D & 527 & $569 \mathrm{sh}$ & $641 \mathrm{sh}$ \\
RuNAA & 525 & $572 \mathrm{sh}$ & $642 \mathrm{sh}$
\end{tabular}


RuIAA
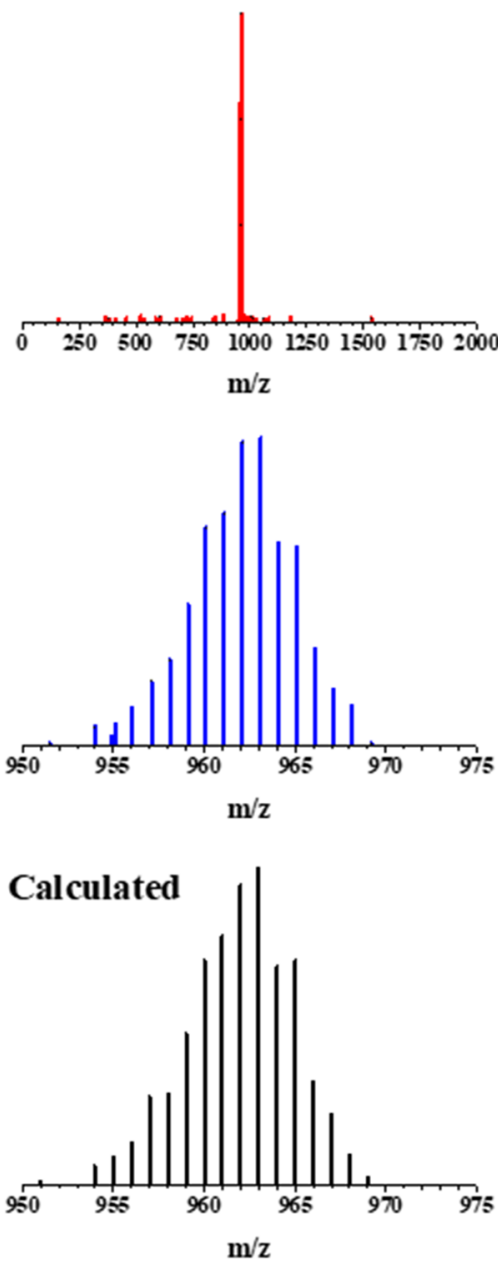

Ru2,4-D

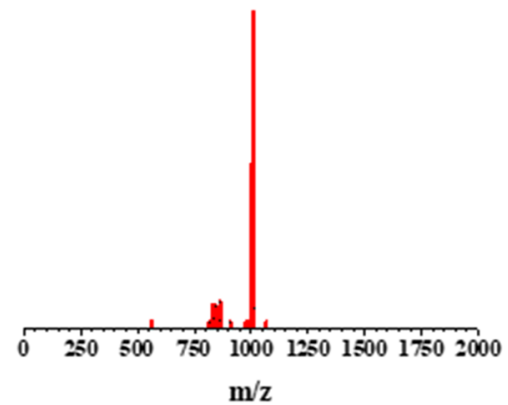

RuNAA

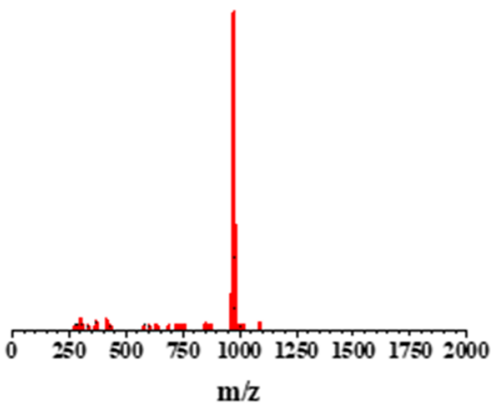

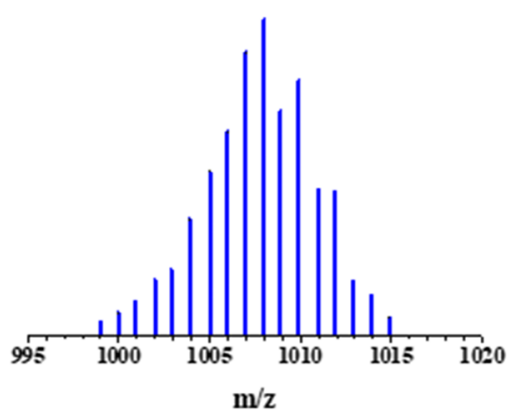
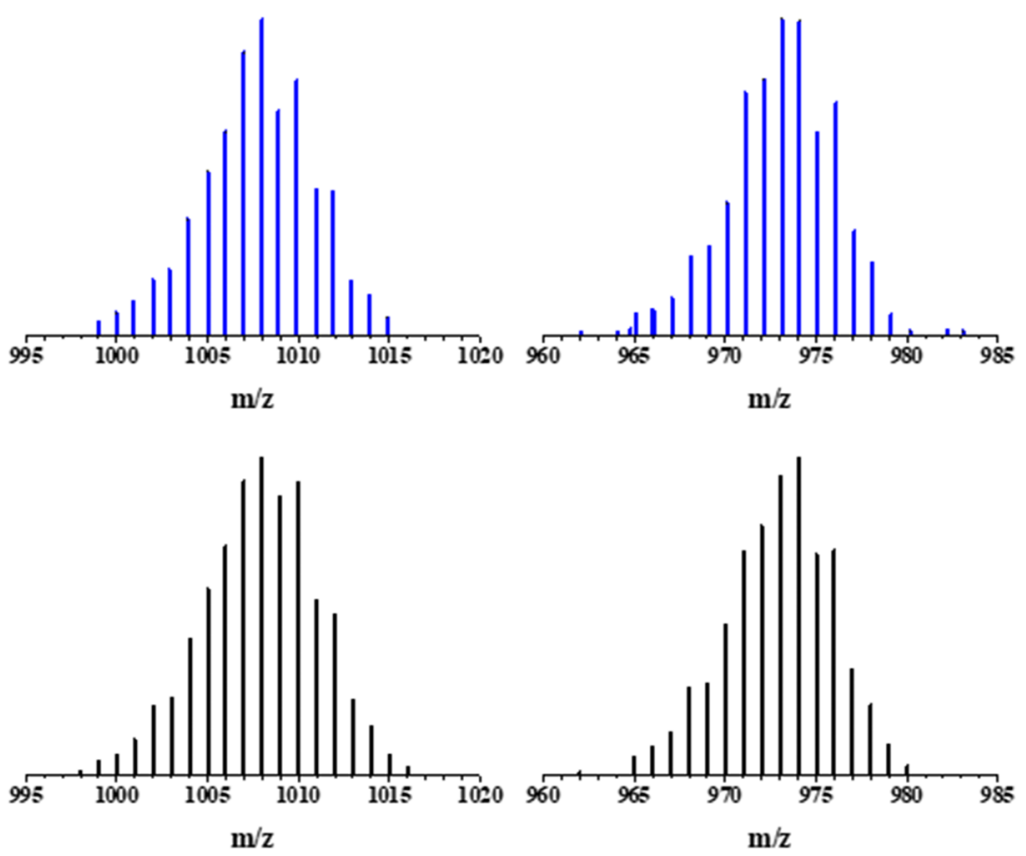

Figure 2. (top) ESI ${ }^{+}$spectra of RuIAA (left), Ru2,4-D (center), and RuNAA (right). (middle) Enlargement of the peak corresponding to the [M $\mathrm{Cl}^{+}$base peak for RuIAA (left), Ru2,4-D (center), and RuNAA (right). (bottom) Calculated spectra of the $[\mathrm{M}-\mathrm{Cl}]^{+}$ion for RuIAA (left), Ru2,4-D (center), and RuNAA (right). Nominal molecular masses and distribution isotopes were calculated with the MASAS ${ }^{37}$ software.

Table 4. Selected Bond Lengths ( $\AA$ ) and Angles (deg) for Compounds RuIAA, Ru2,4-D·C $\mathrm{CH}_{2} \mathrm{Cl}_{2}$, and RuNAA·0.5THF

\begin{tabular}{|c|c|c|c|c|}
\hline & RuIAA & RuIAA $\cdot T H F$ & $\mathrm{Ru} 2,4-\mathrm{D} \cdot \mathrm{CH}_{2} \mathrm{Cl}_{2}$ & RuNAA 0.5 THF \\
\hline $\mathrm{Ru} 1-\mathrm{Ru} 2$ & $2.3162(5)$ & $2.3147(3)$ & $2.3202(4)$ & $2.3213(4)$ \\
\hline $\mathrm{Ru} 1-\mathrm{Cl} 1$ & $2.397(1)$ & $2.4294(7)$ & $2.3889(9)$ & $2.3899(9)$ \\
\hline Ru1-O1 & $2.090(3)$ & $2.094(2)$ & $2.115(3)$ & $2.082(3)$ \\
\hline Ru1-N1 & $2.095(4)$ & $2.072(2)$ & $2.087(2)$ & $2.081(3)$ \\
\hline Ru1-N3 & $2.070(5)$ & $2.067(2)$ & $2.055(4)$ & $2.069(3)$ \\
\hline Ru1-N5 & $2.079(4)$ & $2.084(2)$ & $2.080(2)$ & $2.097(3)$ \\
\hline $\mathrm{Ru} 2-\mathrm{O} 2$ & $2.061(3)$ & $2.065(2)$ & $2.063(3)$ & $2.085(3)$ \\
\hline $\mathrm{Ru} 2-\mathrm{N} 2$ & $2.050(4)$ & $2.040(2)$ & $2.043(2)$ & $2.047(2)$ \\
\hline Ru2-N4 & $2.012(5)$ & $2.004(2)$ & $2.023(4)$ & $2.020(3)$ \\
\hline Ru2-N6 & $2.043(4)$ & $2.046(2)$ & $2.034(2)$ & $2.042(3)$ \\
\hline $\mathrm{Cl} 1-\mathrm{Ru} 1-\mathrm{Ru} 2$ & $178.43(3)$ & $173.96(2)$ & $173.54(3)$ & $173.52(3)$ \\
\hline N1-Ru1-N5 & $175.1(1)$ & $174.82(9)$ & $175.7(1)$ & $173.6(1)$ \\
\hline N3-Ru1-O1 & $175.9(1)$ & $176.42(8)$ & $175.5(1)$ & $176.1(1)$ \\
\hline N2-Ru2-N6 & $178.7(2)$ & $176.07(4)$ & $174.8(1)$ & $176.4(1)$ \\
\hline $\mathrm{N} 4-\mathrm{Ru} 2-\mathrm{O} 2$ & $176.9(1)$ & $178.47(9)$ & $178.5(1)$ & $178.6(1)$ \\
\hline
\end{tabular}

$$
\chi_{\|}=\left(\frac{N g^{2} \beta^{2}}{k_{\mathrm{B}} T}\right)\left[\frac{1+9 \exp \left(\frac{-2 D}{k_{\mathrm{B}} T}\right)}{4\left(1+\exp \left(\frac{-2 D}{k_{\mathrm{B}} T}\right)\right)}\right]
$$

$$
\chi_{\perp}=\left(\frac{N g^{2} \beta^{2}}{k_{\mathrm{B}} T}\right)\left[\frac{4+\left(\frac{3 k_{\mathrm{B}} T}{D}\right)\left(1-\exp \left(\frac{-2 D}{k_{\mathrm{B}} T}\right)\right.}{4\left(1+\exp \left(\frac{-2 D}{k_{\mathrm{B}} T}\right)\right)}\right]
$$

where $N, g, \beta, k_{\mathrm{B}}$, and $D$ have their usual meanings. 


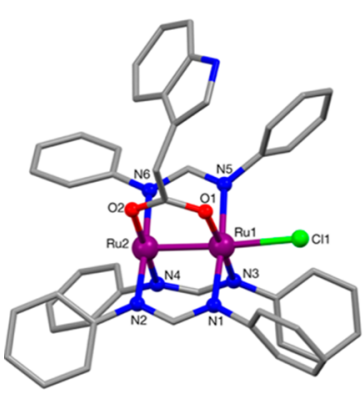

RuIAA

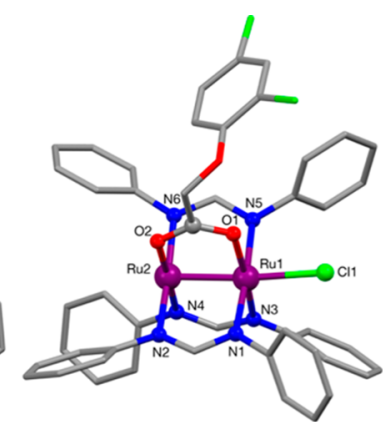

Ru2,4-D

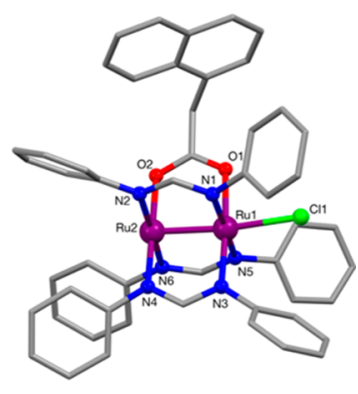

RuNAA

Figure 3. View of the paddlewheel molecules of RuIAA (from the structure of RuIAA·THF), Ru2,4-D, and RuNAA, with selected atoms labeled. Hydrogen atoms and solvent molecules are omitted for clarity.

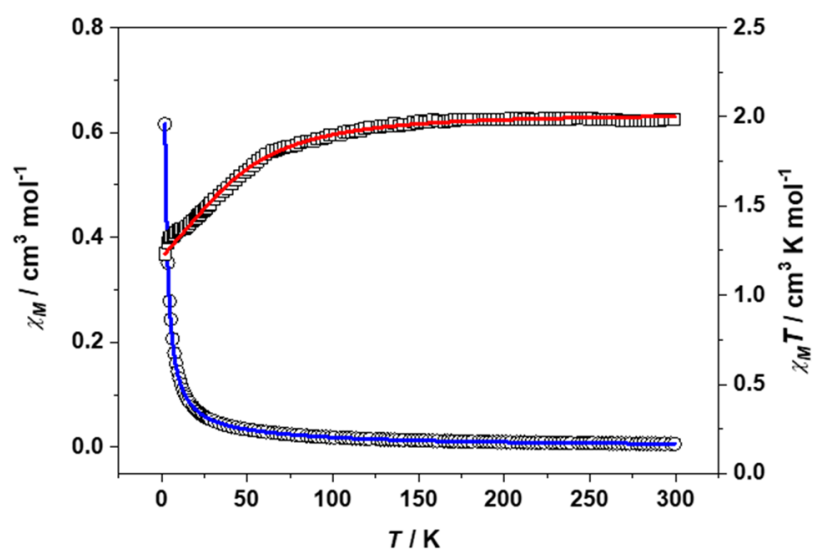

Figure 4. Temperature dependence of the molar susceptibility $\chi_{\mathrm{M}}$ (circles) and $\chi_{\mathrm{M}} T$ (squares) for RuIAA. Solid lines are the best fit to the data as described in the text.

The values obtained from the fit of the data are shown in Table 5 together with the $\sigma^{2}$ values that indicate the quality of

Table 5. Magnetic Parameters Obtained from the Fit of the Experimental Magnetic Data of RuIAA, Ru2,4-D, and RuNAA

\begin{tabular}{llll} 
& \multicolumn{1}{c}{ RuIAA } & \multicolumn{1}{c}{ Ru2,4-D } & \multicolumn{1}{c}{ RuNAA } \\
$g$ & 2.07 & 2.03 & 2.04 \\
$D\left(\mathrm{~cm}^{-1}\right)$ & 50 & 53 & 64 \\
$\sigma^{2 a}$ & $2.42 \times 10^{-4}$ & $2.17 \times 10^{-4}$ & $3.78 \times 10^{-4}$ \\
${ }^{2} \sigma^{2}=\sum\left(\chi_{\mathrm{M}} T_{\text {calcd }}-\chi_{\mathrm{M}} T_{\text {expt }}\right)^{2} / \sum\left(\chi_{M} \cdot T_{\text {expt }}\right)^{2}$. & \\
\hline
\end{tabular}

the fits. The use of this model gives good agreements with the experimental data with $\sigma^{2}$ values in the $(2.17-3.78) \times 10^{-4}$ range. The values found for the gyromagnetic constant $(g)$ are in the range 2.03-2.07 and for the zero-field splitting parameter (D) are in the range $50-64 \mathrm{~cm}^{-1}$, which are similar to those of other related complexes. $^{11,51}$

The data were also fitted using the model of Cukiernik et al., 52 which considers O'Connor's equations with Telser and Drago's corrections. $^{53,54}$ These fittings consider not only the zero-field splitting parameter $(D)$ and the gyromagnetic constant $(g)$ but also a weak intermolecular coupling $(z J)$ and a temperatureindependent paramagnetism (TIP) term (eqs S1-S5 in the Supporting Information). However, the use of this model did not lead to a significantly better quality of the fits, and very small values were obtained for the TIP and $z$ J parameters.
Auxin Activity Measurement. A very sensitive biological assay to qualitatively measure the release of the auxin ligand from the diruthenium compounds was set up. The advantage of this type of assay is that it also provides information on the ability of the released ligand to have a measurable effect at the cellular level. For this purpose, a transgenic Arabidopsis plant carrying a highly active synthetic auxin reporter element was used, which drives the expression of the $\beta$-glucuronidase (GUS) gene in the presence of auxin. ${ }^{29}$ This reporter is widely used because it responds quickly at low concentrations of auxin (in the micromolar range). Also importantly, it detects effects at the end of the signaling pathway, which include release and transport. The GUS activity was detected histochemically using the GUS substrate X-Gluc which liberates a product that accumulates at the site of the enzyme activity as a blue precipitate (Figure 5). Long-term (6 days) treatment of plants with diruthenium species without auxin ligands does not affect their normal growth, and treatment with the RuAux or free Aux produces the same plant phenotype (Figure S15). These results indicate that any difference in RuAux activity at short times can be ascribed specifically to the kinetic of the ligand release.

Auxin is normally produced during plant development and accumulates at the tip of the root (Figure 5G). The treatment with $\left[\mathrm{Ru}_{2} \mathrm{Cl}_{2}(\mu \text {-DPhF })_{3}\right]$ alone during $24 \mathrm{~h}$ was carried out as a control, and the auxin pattern in the root was not modified (Figure $5 \mathrm{H}$ ). Then, plants were treated in parallel with the free auxin and the same auxin-coordinated diruthenium compound in different buffers at $\mathrm{pH} 6.5,7.0$, and 7.5. The histochemical staining was performed at different time points to evaluate qualitatively the action of each phytohormone. Since the effect of the three auxins might be significantly different ${ }^{55}$ and be influenced by the $\mathrm{pH}$ of the media, we compared the results of treatment with each auxin to those of its corresponding diruthenium derivative for each experimental condition. Treatment with exogenous KNAA led to an increase in GUS activity first in the proximal part of the root, as soon as after $1.5 \mathrm{~h}$, and in the more distal part at longer treatment times (Figure 5B,D,F). At $\mathrm{pH}$ 6.5, the auxin activity of plants treated with RuNAA was also detectable after $1.5 \mathrm{~h}$ of treatment and increased to levels comparable to that of the sample treated with KNAA at $6 \mathrm{~h}$ (Figure 5A,B), indicating that at this $\mathrm{pH}$ the NAA release from the RuNAA occurs very quickly. At $\mathrm{pH} 7$, a delay in the release of the auxin moiety was observed and became detectable after $2.5 \mathrm{~h}$ of treatment (Figure 5C,D). At pH 7.5, the plants treated during 6-24 h with KNAA showed less auxin activity in comparison to that at slightly acidic or neutral $\mathrm{pH}$ (Figure 5B,D,F). This was also true for the other auxins studied, NaIAA and H2,4-D 


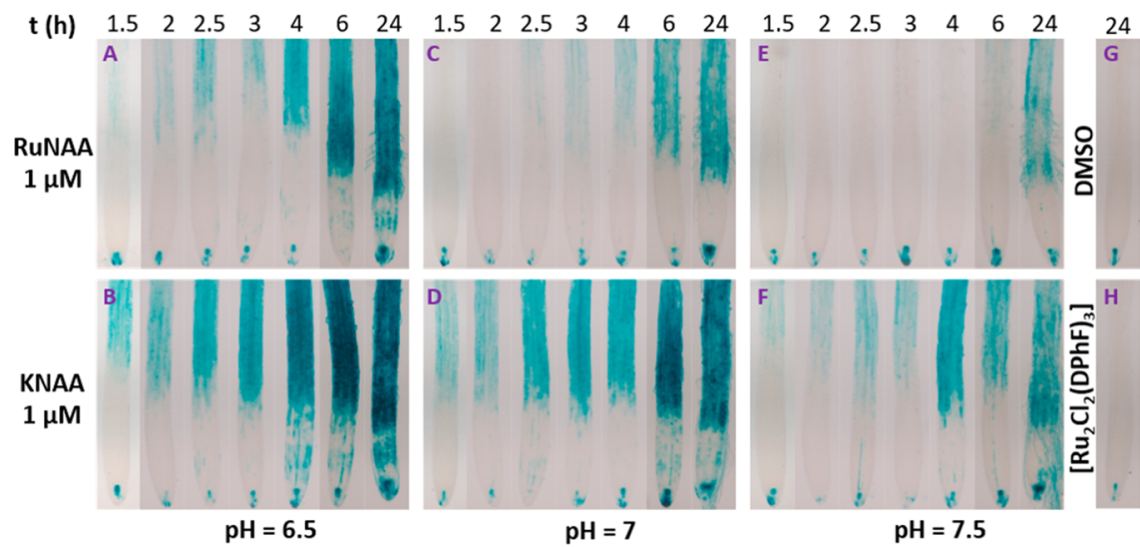

Figure 5. Histochemical localization of auxin activity in Arabidopsis roots reflected by the activity of the DR5 promoter driving GUS expression (pDR5::GUS). Five-day-old plants were treated from 1.5 to $24 \mathrm{~h}$ with the compound RuNAA (A, C, E) or KNAA (B, D, F) at $1 \mu$ M in 5 mM HEPES buffer at $\mathrm{pH}$ 6.5 (A, B), 7 (C, D), and 7.5 (E, F). Plants treated during $24 \mathrm{~h}$ with DMSO $(\mathrm{G})$ or $\left[\mathrm{Ru}_{2} \mathrm{Cl}_{2}(\mu \text {-DPhF })_{3}\right]$ at $1 \mu \mathrm{M}(\mathrm{H})$ were used as controls. GUS activity was detected as a blue precipitate by incubating the plants with the substrate X-Gluc.

(Figure S16). However, interestingly, when the activities of RuNAA and KNAA at $\mathrm{pH} 7.5$ are compared, no auxin activity can be detected in plants treated with RuNAA until $6 \mathrm{~h}$, indicative of a delay in the release of the active species from the diruthenium complex (Figure 5E,F). A similar effect could be also detected for RuIAA and Ru2,4-D (Figure S16). These results indicate that the kinetics of the auxin release depends on the $\mathrm{pH}$. The $\mathrm{p} K_{\mathrm{a}}$ values of HIAA, HNAA, and $\mathrm{H} 2,4-\mathrm{D}$ are 4.7, 4.2, and 2.7, respectively. Therefore, the phytohormones are predominantly in their anionic forms in solution at $\mathrm{pH} 6.5,7$, or 7.5. However, the release of the auxin from the diruthenium complex requires its protonation and is favored in acidic $\mathrm{pH}$. Thus, it has been shown experimentally that the release occurs more quickly at acidic and neutral $\mathrm{pH}$ than in slightly alkaline media.

It has been reported that the formation of noncovalent auxin complexes with cucurbit[7] uril macrocyle, $\mathrm{CB}[7]$, is also pHdependent and takes place only at $\mathrm{pH}<\mathrm{p} K_{\mathrm{a}} .{ }^{56} \mathrm{CB}[7]$ has also been recently used to functionalize a dendrimer to carry a guestmodified doxorubicin, an anticancer drug used in chemotherapy. This prodrug is attached via a $\mathrm{pH}$-sensitive linker to facilitate its release at the sites of the disease. The delivery depends on the hydrolysis of the linker, which increases with lowering $\mathrm{pH}$. However, the stability of the $\mathrm{CB}[7]$-guest complex prevents a sufficient release even at low $\mathrm{pH} .{ }^{57}$ In the present work, the auxin is covalently bonded to the diruthenium complex and is more stable, at least kinetically, at $\mathrm{pH}>7$. Nevertheless, the ligand can be progressively released to the medium in a reasonable time to be assimilated by the plants.

\section{CONCLUSIONS}

The synthetic strategy using an open-paddlewheel compound, $\left[\mathrm{Ru}_{2} \mathrm{Cl}_{2}(\mu-\mathrm{DPhF})_{3}\right]$, to incorporate biologically active, often sensitive species to diruthenium fragments has been successful to prepare $\left[\mathrm{Ru}_{2} \mathrm{Cl}(\mu \text {-DPhF })_{3}(\mu\right.$-IAA $\left.)\right](\operatorname{RuIAA}), \quad\left[\mathrm{Ru}_{2} \mathrm{Cl}(\mu\right.$ $\left.\mathrm{DPhF})_{3}(\mu-2,4-\mathrm{D})\right](\mathbf{R u} 2,4-\mathrm{D})$, and $\left[\mathrm{Ru}_{2} \mathrm{Cl}(\mu-\mathrm{DPhF})_{3}(\mu\right.$ NAA) ] (RuNAA) (DPhF $=N, N^{\prime}$-diphenylformamidinate; IAA = indole-3-acetate, 2,4-D = 2,4-dichlorophenoxyacetate, NAA = 1-naphthaleneacetate) under mild conditions and with good yields. These compounds have been structurally characterized by single-crystal X-ray diffraction. In fact, RuIAA constitutes a rare example of a coordination compound with the natural auxin IAA, whose crystal structure has been determined.
The auxin activity of RuIAA, Ru2,4-D, and RuNAA in Arabidopsis thaliana depends on the release of the auxin ligands, which is progressive and occurs more slowly in slightly alkaline media. These results confirm our hypothesis and reinforce the idea of employing these types of diruthenium compounds as molecule carriers. Further work will be needed to incorporate other ligands functionalized with carboxylate groups such as anticancer drugs. However, in order to employ them in vivo, it would be necessary to study the influence of the other bridging ligands in the delivery process and the use of auxiliary ligands to increase the solubility in water of the compounds.

\section{ASSOCIATED CONTENT}

\section{Supporting Information}

The Supporting Information is available free of charge at https://pubs.acs.org/doi/10.1021/acs.inorgchem.0c00844.

Asymmetric unit of RuIAA, sample and crystal data for RuIAA, data collection and structure refinement details for RuIAA, asymmetric unit of RuIAA ·THF, sample and crystal data for RuIAA $\cdot$ THF, data collection and structure refinement details for RuIAA·THF, overlay of RuIAA molecules in the crystal structures of RuIAA and RuIAA THF, asymmetric unit of $\mathbf{R u 2 , 4 - D} \cdot \mathrm{CH}_{2} \mathbf{C l}_{2}$, sample and crystal data for $\mathrm{Ru}$ 2,4-D $\cdot \mathrm{CH}_{2} \mathrm{Cl}_{2}$, data collection and structure refinement details for $\mathrm{Ru2}, 4-\mathrm{D} \cdot \mathrm{CH}_{2} \mathrm{Cl}_{2}$, asymmetric unit of RuNAA 0.5 THF, sample and crystal data for RuNAA·0.5THF, data collection and structure refinement for RuNAA-0.5THF, $\mathrm{N}-\mathrm{H} \cdots \mathrm{Cl}$ hydrogen bonds between paddlewheel molecules found in both RuIAA and RuIAA·THF, supramolecular interactions between RuIAA molecules considering both the stronger $\mathrm{N}-\mathrm{H} \cdots \mathrm{Cl}$ bonds and weaker $\mathrm{C}-\mathrm{H} \cdots \mathrm{O}$ bonds, PXRD of RuIAA and simulated diffractograms of RuIAA $\cdot$ THF and RuIAA calculated from single-crystal X-ray diffraction data, PXRD of Ru2,4-D, PXRD of RuNAA, IR spectra of RuIAA, Ru2,4-D, and RuNAA, electronic spectra of $\left[\mathrm{Ru}_{2} \mathrm{Cl}(\mu \text {-DPhF })_{3}\left(\mu-\mathrm{O}_{2} \mathrm{CMe}\right)\right]$, RuIAA, Ru2,4-D, and RuNAA, temperature dependence of the molar susceptibility $\chi_{M}$ and $\chi_{M} T$ for Ru2,4-D, temperature dependence of the molar susceptibility $\chi_{\mathrm{M}}$ and $\chi_{\mathrm{M}} T$ for RuNAA, equations employed to perform an alternative fitting of the data of RuIAA, Ru2,4-D, and RuNAA following the model of Cukiernik et al., phenotype of Arabidopsis 
thaliana plants treated with $\left[\mathrm{Ru}_{2} \mathrm{Cl}_{2}(\mathrm{DPhF})_{3}\right]$, the different RuAux compounds, and their corresponding free auxin, histochemical localization of auxin activity in Arabidopsis roots reflected by the activity of the DR5 promoter driving GUS expression (pDR5::GUS) (PDF)

\section{Accession Codes}

CCDC 1988474-1988477 contain the supplementary crystallographic data for this paper. These data can be obtained free of charge via www.ccdc.cam.ac.uk/data_request/cif, or by emailing data_request@ccdc.cam.ac.uk, or by contacting The Cambridge Crystallographic Data Centre, 12 Union Road, Cambridge CB2 1EZ, UK; fax: +44 1223336033.

\section{AUTHOR INFORMATION}

\section{Corresponding Authors}

Bénédicte Desvoyes - Centro de Biología Molecular Severo Ochoa, CSIC-UAM, E-28049 Madrid, Spain; ๑ orcid.org/ 0000-0001-7116-9821; Email: bdesvoyes@cbm.csic.es

Santiago Herrero - Departamento de Química Inorgánica, Facultad de Ciencias Quimicas, Universidad Complutense de Madrid, E-28040 Madrid, Spain; ๑ orcid.org/0000-00029901-1142; Email: sherrero@ucm.es

\section{Authors}

Isabel Coloma - Departamento de Química Inorgánica, Facultad de Ciencias Químicas, Universidad Complutense de Madrid, E28040 Madrid, Spain; @ orcid.org/0000-0002-4969-9479

Miguel Cortijo - Departamento de Química Inorgánica, Facultad de Ciencias Químicas, Universidad Complutense de Madrid, E-28040 Madrid, Spain; ๑ orcid.org/0000-00023970-0720

Inés Fernández-Sánchez - Departamento de Química Inorgánica, Facultad de Ciencias Químicas, Universidad Complutense de Madrid, E-28040 Madrid, Spain

Josefina Perles - Laboratorio de Difracción de Rayos X de Monocristal, Servicio Interdepartamental de Investigación, Universidad Autonoma de Madrid, E-28049 Madrid, Spain; ๑ orcid.org/0000-0003-0256-0186

José L. Priego - Departamento de Química Inorgánica, Facultad de Ciencias Químicas, Universidad Complutense de Madrid, E28040 Madrid, Spain; ๑ orcid.org/0000-0002-5819-8502

Crisanto Gutiérrez - Centro de Biología Molecular Severo Ochoa, CSIC-UAM, E-28049 Madrid, Spain; ๑ orcid.org/ 0000-0001-8905-8222

Reyes Jiménez-Aparicio - Departamento de Química Inorgánica, Facultad de Ciencias Químicas, Universidad Complutense de Madrid, E-28040 Madrid, Spain; ๑ orcid.org/ 0000-0002-1030-8194

Complete contact information is available at: https://pubs.acs.org/10.1021/acs.inorgchem.0c00844

\section{Author Contributions}

S.H. and B.D. designed the study, I.C., M.C., and I.F.-S. performed the synthesis and general characterization of the compounds, B.D. and I.C. carried out the biological assays, J.P. and M.C. were responsible for the crystal structure characterization, all authors contributed to the analysis and interpretation of data, S.H. and B.D. directed the project with the support of R.J.-A., J.L.P., C.G., and M.C., S.H., R.J.-A., and M.C. wrote the manuscript with the input of all authors.

\section{Funding}

This research was funded by the Comunidad de Madrid (project B2017/BMD-3770-CM) to S.H., by the Ministerio de Ciencia, Universidades e Innovación (MICIU), and FEDER (RTI2018094793-B-I00) to C.G., and by institutional grants from Fundación Ramón Areces and Banco de Santander to the Centro de Biologia Molecular Severo Ochoa.

\section{Notes}

The authors declare no competing financial interest.

\section{DEDICATION}

Dedicated to the memory of Profs. José Antonio Campo and Emilio Morán, who died of Covid-19.

\section{REFERENCES}

(1) Jahangirian, H.; Kalantari, K.; Izadiyan, Z.; Rafiee-Moghaddam, R.; Shameli, K.; Webster, T. J. A review of small molecules and drug delivery applications using gold and iron nanoparticles. Int. J. Nanomed. 2019, 14, 1633-1657.

(2) Dzhardimalieva, G. I.; Rabinskiy, L. N.; Kydralieva, K. A.; Uflyand, I. E. Recent advances in metallopolymer-based drug delivery systems. RSC Adv. 2019, 9, 37009-37051.

(3) Renfrew, A. K. Transition metal complexes with bioactive ligands: mechanisms for selective ligand release and applications for drug delivery. Metallomics 2014, 6, 1324-1335.

(4) De Oliveira Silva, D. Perspectives for Novel Mixed DirutheniumOrganic Drugs as Metallopharmaceuticals in Cancer Therapy. AntiCancer Agents Med. Chem. 2010, 10, 312-323.

(5) Cotton, F. A.; Murillo, C. A.; Walton, R. A. Multiple Bonds between Metal Atoms, 3rd ed.; Springer: New York, 2005.

(6) Liddle, S. T. Molecular Metal-Metal Bonds: Compounds, Synthesis, Properties; Wiley-VCH: Weinheim, Germany, 2015.

(7) Aquino, M. A. S. Diruthenium and diosmium tetracarboxylates: synthesis, physical properties and applications. Coord. Chem. Rev. 1998, 170, 141-202.

(8) Aquino, M. A. S. Recent developments in the synthesis and properties of diruthenium tetracarboxylates. Coord. Chem. Rev. 2004, $248,1025-1045$.

(9) Cotton, F. A.; Matusz, M.; Zhong, B. Oxidation states available to the $\mathrm{Ru}_{2}{ }^{\mathrm{n}+}$ core in tetracarboxylato-bridged species. Inorg. Chem. 1988, $27,4368-4372$.

(10) Norman, J. G.; Renzoni, G. E.; Case, D. A. Electronic Structure of $\mathrm{Ru}_{2}\left(\mathrm{O}_{2} \mathrm{CR}\right)_{4}{ }^{+}$and $\mathrm{Rh}_{2}\left(\mathrm{O}_{2} \mathrm{CR}\right)_{4}{ }^{+}$Complexes. J. Am. Chem. Soc. 1979, $101,5256-5267$.

(11) Cortijo, M.; González-Prieto, R.; Herrero, S.; Priego, J. L.; Jiménez-Aparicio, R. The use of amidinate ligands in paddlewheel diruthenium chemistry. Coord. Chem. Rev. 2019, 400, 213040.

(12) Raghavan, A.; Ren, T. Bisaryl Diruthenium(III) Paddlewheel Complexes: Synthesis and Characterization. Organometallics 2019, 38, $3888-3896$.

(13) Angaridis, P. A.; Cotton, F. A.; Murillo, C. A.; Filato, A. S.; Petrukhina, M. A. Diruthenium formamidinato complexes. Inorganic Syntheses 2014, 36, 114-121.

(14) Lozano, G.; Jiménez-Aparicio, R.; Herrero, S.; Martínez-Salas, E. Fingerprinting the junctions of RNA structure by an open-paddlewheel diruthenium compound. RNA 2016, 22, 330-380.

(15) Valentín-Pérez, A.; Perles, J.; Herrero, S.; Jiménez-Aparicio, R. Coordination capacity of cytosine, adenine and derivatives towards open-paddlewheel diruthenium compounds. J. Inorg. Biochem. 2018, 187, 109-115.

(16) Bland, B. R. A.; Gilfoy, H. J.; Vamvounis, G.; Robertson, K. N.; Cameron, T. S.; Aquino, M. A. S. Hydrogen bonding in diruthenium(II, III) tetraacetate complexes with biologically relevant axial ligands. Inorg. Chim. Acta 2005, 358, 3927-3936.

(17) Ribeiro, G.; Benadiba, M.; Colquhoun, A.; de Oliveira Silva, D. Diruthenium(II, III) complexes of ibuprofen, aspirin, naproxen and indomethacin non-steroidal anti-inflammatory drugs: Synthesis, 
characterization and their effects on tumor-cell proliferation. Polyhedron 2008, 27, 1131-1137.

(18) Santos, R. L. S. R.; Bergamo, A.; Sava, G.; de Oliveira Silva, D. Synthesis and characterization of a diruthenium(II, III)-ketoprofen compound and study of the in vitro effects on CRC cells in comparison to the naproxen and ibuprofen derivatives. Polyhedron 2012, 42, 175181.

(19) Messori, L.; Marzo, T.; Nazar, R.; Sanches, F.; Rehman, H. U.; de Oliveira Silva, D.; Merlino, A. Unusual Structural Features in the Lysozyme Derivative of the Tetrakis(acetato)chloridodiruthenium(II, III) Complex. Angew. Chem., Int. Ed. 2014, 53, 6172-6175.

(20) Alves Rico, S. R.; Abbasi, A. Z.; Ribeiro, G.; Ahmed, T.; Wu, X. Y.; de Oliveira Silva, D. Diruthenium(II, III) metallodrugs of ibuprofen and naproxen encapsulated in intravenously injectable polymer-lipid nanoparticles exhibit enhanced activity against breast and prostate cancer cells. Nanoscale 2017, 9, 10701-10714.

(21) Miyake, J. A.; Benadiba, M.; Ribeiro, G.; de Oliveira Silva, D.; Colquhoun, A. Novel Ruthenium - Gamma-linolenic acid complex inhibits C6 rat glioma cell proliferation In Vitro and in the orthotopic C6 model In Vivo after osmotic pump infusion. Anticancer Res. 2014, 34 (4), 1901-1912.

(22) Hanif-Ur-Rehman; Freitas, T. E.; Gomes, R. N.; Colquhoun, A.; de Oliveira Silva, D. Axially-modified paddlewheel diruthenium(II, III)ibuprofenato metallodrugs and the influence of the structural modification on U87MG and A172 human glioma cell proliferation, apoptosis, mitosis and migration. J. Inorg. Biochem. 2016, 165, 181191.

(23) Ibrahim-Hashim, A.; Estrella, V. Acidosis and cancer: from mechanism to neutralization. Cancer Metastasis Rev. 2019, 38, 149155 .

(24) Böhme, I.; Bosserhoff, A. K. Acidic tumor microenvironment in human melanoma. Pigm. Cell Melanoma Res. 2016, 29, 508-523.

(25) Webb, B. A.; Chimenti, M.; Jacobson, M. P.; Barber, D. L. Dysregulated $\mathrm{pH}$ : a perfect storm for cancer progression. Nat. Rev. Cancer 2011, 11, 671-677.

(26) Zhang, X.; Lin, Y.; Gillies, R. J. Tumor pH and Its Measurement. J. Nucl. Med. 2010, 51, 1167-1170.

(27) Barral, M. C.; Gallo, T.; Herrero, S.; Jiménez-Aparicio, R.; Torres, M. R.; Urbanos, F. A. The First Open-Paddlewheel Structures in Diruthenium Chemistry: Examples of Intermediate Magnetic Behaviour between Low and High Spin in $\mathrm{Ru}_{2}^{5+}$ Species. Chem. - Eur. J. 2007, 13, 10088-10095.

(28) Skupa, P.; Opatrný, Z.; Petrášek, J. Auxin Biology: Applications and the Mechanisms Behind. Plant Cell Monogr. 2014, 22, 69-102.

(29) Ulmasov, T.; Murfett, J.; Hagen, G.; Guilfoyle, T. J. Aux/IAA proteins repress expression of reporter genes containing natural and highly active synthetic auxin response elements. Plant Cell 1997, 9, 1963-1971.

(30) Schindelin, J.; Arganda-Carreras, I.; Frise, E.; Kaynig, V.; Longair, M.; Pietzsch, T.; Preibisch, S.; Rueden, C.; Saalfeld, S.; Schmid, B.; Tinevez, J. Y.; White, D. J.; Hartenstein, V.; Eliceiri, K.; Tomancak, P.; Cardona, A. Fiji: an open-source platform for biological-image analysis. Nat. Methods 2012, 9, 676-682.

(31) Barral, M. C.; Gallo, T.; Herrero, S.; Jiménez-Aparicio, R.; Torres, M. R.; Urbanos, F. A. Equatorially Connected Diruthenium(II, III) Units toward Paramagnetic Supramolecular Structures with Singular Magnetic Properties. Inorg. Chem. 2006, 45, 3639-3647.

(32) Añez, E.; Herrero, S.; Jiménez-Aparicio, R.; Priego, J. L.; Torres, M. R.; Urbanos, F. A. Controlling the electronic density of the $\left[\mathrm{Ru}_{2}(\mathrm{DPhF})_{3}\left(\mathrm{O}_{2} \mathrm{CR}\right)\right]^{+}$core to obtain one-dimensional compounds. Polyhedron 2010, 29, 232-237.

(33) Herrero, S.; Jiménez-Aparicio, R.; Perles, J.; Priego, J. L.; Saguar, S.; Urbanos, F. A. Microwave methods for the synthesis of paddlewheel diruthenium compounds with N, N-donor ligands. Green Chem. 2011, $13,1885-1890$.

(34) Barral, M. C.; Herrero, S.; Jiménez-Aparicio, S.; Priego, J. L.; Torres, M. R.; Urbanos, F. A. Activation of isocyanate ligands in $\mathrm{Ru}_{2}^{5+}$ complexes. J. Mol. Struct. 2008, 890, 221-226.
(35) Nakamoto, K. Infrared and Raman Spectra of Inorganic and Coordination Compounds, Part B, Applications in Coordination, Organometallic and Bioinorganic Chemistry, 6th ed.; Wiley: Hoboken, NJ, 2009.

(36) Lin, C.; Ren, T.; Valente, E. J.; Zubkowski, J. D.; Smith, E. T. Continuous Spectroscopic and Redox Tuning of Dinuclear Compounds: Chlorotetrakis $(\mu$-N, N'-diarylformamidinato)diruthenium(II,III). Chem. Lett. 1997, 26, 753-754.

(37) Urbanos, F. A. Software MASAS, ver. 3.1; Universidad Complutense de Madrid: Madrid, 2002.

(38) Groom, C. R.; Bruno, I. J.; Lightfoot, M. P.; Ward, S. C. The Cambridge Structural Database. Acta Crystallogr., Sect. B: Struct. Sci., Cryst. Eng. Mater. 2016, B72, 171-179.

(39) Zhongle, H.; Xiufen, Y. Bis (N, $N^{\prime}$-dimethylformamide)tetrakis( $\mu_{2}$-indolyl-3-acetato-O, $\left.O^{\prime}\right)$ dicopper(II). Jiegou Huaxue (Chin. J. Struct. Chem.) (Chin.) 1988, 7, 130.

(40) Reck, G.; Jähnig, W. Molecular and Crystal Structure of Dioxanobis(2,4-dichlorophenoxyacetato)-copper (II) $\mathrm{Cu}_{2}(2,4-\mathrm{D})_{4} \cdot 5$ Dioxan. J. Prakt. Chem. 1979, 321, 549-554.

(41) Smith, G.; O’Reilly, E. J.; Kennard, C. H. L. Metalphenoxyalkanoic acid interactions. Part 3. Crystal and molecular structures of tetra- $\mu$-(2,4-dichlorophenoxyacetato)bis[aquacopper(II)] dihydrate and tetra- $\mu$-(2,4,5-trichlorophenoxyacetato)bis[pyridinecopper(II)]. Inorg. Chim. Acta 1981, 49, 53-61.

(42) Wang, R.-S.; Feng, J.; Lian, M.-L.; Kong, D.-S.; Lei, Y.-Z.; Shi, K.Y. CCDC 1811867: Experimental Crystal Structure Determination, 2019.

(43) Huang, P.-Y.; Wang, J.-G. Catena-Poly[ [tetrakis $(\mu$-2,4-dichlorophenoxyacetato- $\left.\kappa^{2} \mathrm{O}: \mathrm{O}^{\prime}\right)$ dicopper(II)]- $\mu$-pyrazine- $\left.\kappa^{2} \mathrm{~N}: \mathrm{N}^{\prime}\right]$. Acta Crystallogr., Sect. E: Struct. Rep. Online 2007, 63, No. m645.

(44) Yang, Y.-Q.; Li, C.-H.; Li, W.; Kuang, Y. F. CCDC 781765: Experimental Crystal Structure Determination, 2011.

(45) Drzewiecka-Antonik, A.; Ferenc, W.; Wolska, A.; Klepka, M. T.; Cristovao, B.; Sarzynski, J.; Rejmak, P.; Osypiuk, D. The Co(II), Ni(II) and $\mathrm{Cu}(\mathrm{II})$ complexes with herbicide 2,4-dichlorophenoxyacetic acid Synthesis and structural studies. Chem. Phys. Lett. 2017, 667, 192-198.

(46) (a) Yin, F.-J.; Gu, Y.; Zhao, H.; Bai, D. S. Tetrakis $(\mu$ naphthalene-1-acetato- $\left.\kappa^{2} \mathrm{O}: \mathrm{O}^{\prime}\right)$ bis $[(\mathrm{N}, \mathrm{N}$-dimethylformamide- $\kappa \mathrm{O})$ copper(II)]. Acta Crystallogr., Sect. E: Struct. Rep. Online 2012, E68, No. m350. (b) Marsh, R. E. Space group P1: an update. Acta Crystallogr., Sect. B: Struct. Sci. 2005, B61, 359.

(47) Chen, L.-F.; Zhang, J.; Song, L.-J.; Wang, W.-G.; Ju, Z.-F. Tetrakis- $\left(\mu-\alpha\right.$-naphthyl-acetato- $\left.\kappa^{2} \mathrm{O}: \mathrm{O}^{\prime}\right)$ bis $[($ dimethyl sulfoxide- $\kappa \mathrm{O})$ copper(II)]- $\alpha$-naphthylacetic acid-dimethyl sulfoxide $(1 / 2 / 2)$. Acta Crystallogr., Sect. E: Struct. Rep. Online 2004, 60, No. m1032.

(48) Yin, F.-J.; Zhao, H.; Xu, X.-Y.; Yang, X.-J. Synthesis, Crystal Structure, and Properties of a Tetranuclear Copper(II) Complex With $\alpha$-Naphthylacetic Acid. Synth. React. Inorg., Met.-Org., Nano-Met. Chem. 2014, 44, 101-110.

(49) Li, Y.-M.; Xiao, C.-Y.; Feng, H.-R.; Guo, S.-S.; Wang, S.-B. Two binuclear tetracarboxylate-bridged complexes: syntheses, structures, and properties. J. Coord. Chem. 2012, 65, 2820-2829.

(50) O’Rourke, N. F.; Ronaldson, M.; Cameron, T. S.; Wang, R.; Aquino, M. A. S. Equatorial $\pi$-stacking interactions in diruthenium (II, III) tetracarboxylate complexes containing extended $\pi$-systems. J. Mol. Struct. 2013, 1052, 17-23.

(51) Chen, W.-Z.; Cotton, F. A.; Dalal, N. S.; Murillo, C. A.; Ramsey, C. M.; Ren, T.; Wang, X. Proof of Large Positive Zero-Field Splitting in a $\mathrm{Ru}_{2}^{5+}$ Paddlewheel. J. Am. Chem. Soc. 2005, 127, 12691-12696.

(52) Cukiernik, F. D.; Luneau, D.; Marchon, J. C.; Maldivi, P. MixedValent Diruthenium Long-Chain Carboxylates. 2. Magnetic Properties. Inorg. Chem. 1998, 37, 3698-3704.

(53) Telser, J.; Drago, R. S. Reinvestigation of the electronic and magnetic properties of ruthenium butyrate chloride. Inorg. Chem. 1984, $23,3114-3120$

(54) Telser, J.; Drago, R. S. Correction: Reinvestigation of the Electronic and Magnetic Properties of Ruthenium Butyrate Chloride. Inorg. Chem. 1985, 24, 4765.

(55) Enders, T. A.; Strader, L. C. Auxin activity: past, present, and future. Am. J. Bot. 2015, 102, 180-196. 
(56) Nuzzo, A.; Scherman, O. A.; Mazzei, P.; Piccolo, A. pHcontrolled release of auxin plant hormones from cucurbit[7]uril macrocycle. Chem. Biol. Technol. Agric. 2014, 1, 2.

(57) Zou, L.; VandenBerg, M. A.; Webber, M. J. Single-molecule nanoscale drug carriers with quantitative supramolecular loading. Mol. Syst. Des. Eng. 2020, 5, 197-204. 